\title{
Compatibility of entomopathogenic nematodes (Nematoda: Rhabditida) and the biocide, spinosad for mitigation of the armyworm, Spodoptera litura (F.) (Lepidoptera: Noctuidae)
}

Rashad R. Khan ${ }^{1,2^{*}}$, Rameesha A. Ali ${ }^{2}$, Abid Ali ${ }^{2}$, Muhammad Arshad², Shahid Majeed², Sohail Ahmed², Sajid A. Khan ${ }^{3}$ and Muhammad Arshad ${ }^{4}$

\begin{abstract}
Two entomopathogenic nematodes (EPNs) Heterorhabditis indica and Steinernema carpocapsae were tested against the armyworm, Spodoptera litura (F.) (Lepidoptera: Noctuidae). Also, their compatibility with spinosad (Tracer ${ }^{\oplus}$ 240SC) was assessed under laboratory conditions. In study I, compatibility test was performed to evaluate the viability of nematodes at different concentrations of spinosad. None of the concentrations was observed as toxic against both EPNs. The highest concentration ( $800 \mathrm{ppm}$ ) of the spinosad showed $14 \%$ mortality in $\mathrm{H}$. indica juveniles and $13 \%$ in S. carpocapsae $48 \mathrm{~h}$ post-treatment. In study II, the spinosad and the EPN mixtures showed that both EPNs enhanced the efficacy of spinosad against S. litura larvae. The highest mortality rates (80.0 and 76. $6 \%)$ in the second instar larvae indicated a synergistic effect $\left(X^{2}=39.69\right.$ and 7.02) $48 \mathrm{~h}$ post-treatment, with infective juveniles (IJs) of S. carpocapsae and H. indica, respectively, with the highest concentration of spinosad. In the case of the third instar larvae, a synergistic effect $\left(X^{2}=16.73\right)$ was observed in $H$. indica and the highest concentration of spinosad, while other treatments showed additive efficacy of the EPNs. After 96 h, all treatments exhibited synergistic effect, except when $H$. indica was applied at the lowest concentration of spinosad. However, these combination treatments need to be tested further with EPNs under field conditions to confirm their efficacy.
\end{abstract}

Keywords: Compatibility, Efficacy, Entomopathogenic nematodes, Spinosad, Spodoptera litura, Synergism

\section{Background}

The armyworms, Spodoptera spp., are among the most important insect pests of agricultural crops (Zhou et al. 2010). They are generalist feeders infesting over 290 plant species that belong to 80-99 families (Wu et al. 2004). They may cause economic losses $(25.8-100 \%)$ to crop growers (Dhir et al. 1992) relying upon the crop stage and level of infestation in the field (Ahmad et al. 2005).

\footnotetext{
* Correspondence: rashadkhan@uaf.edu.pk

${ }^{1}$ Department of Plant Protection, Directorate General of Agriculture and Livestock Research, Ministry of Agriculture and Fisheries, PO Box 50 Seeb, 121 Muscat, Sultanate of Oman

2Department of Entomology, University of Agriculture, Faisalabad 38040, Pakistan

Full list of author information is available at the end of the article
}

A wide variety of synthetic insecticides, belonging to various groups, has been used against lepidopteran pests, including Spodoptera spp. (Saleem et al. 2008). The unsuccessful control and resistance development against certain insecticides have been reported in Pakistan, due to injudicious use (Ahmad and Arif 2010). Alternatively, the bio-pesticides including entomopathogenic nematodes (EPNs), Bacillus thuringiensis and nuclear polyhedrosis viruses (NPVs), have been reported as effective tools in integrated pest management due to their pest selectivity and less toxicity to beneficial arthropods (Wilson et al. 2002). EPNs, especially the members of Steinernematidae and Heterorhabdiridae, have been effectively applied as safe biological insecticides in pest control plans (Grewal et al. 2005) and can be applied 
through standard pesticide machinery (Shapiro-Ilan et al. 2006). However, the significant non-target effect on the larvae of two-spotted lady beetle, Adalia bipunctata (L.), and lacewing, Chrysoperla carnea (Stephens) was mentioned by Rojht et al. (2009). A wide variety of insect pests has been reported to be susceptible to the nematodes showing no adverse effects on beneficial and non-targeted species (Akhurst and Smith 2002).

Considering the lack of information on the interaction of EPNs with spinosad, routinely applied insecticide, the compatibility of spinosad with two EPNs and their synergistic or additive interactions against second and third larval instars of $S$. litura were assessed under laboratory conditions.

\section{Methods}

\section{Insect culture}

The rearing of the nematode host, Galleria mellonella Linnaeus (Lepidoptera: Pyralidae), was carried out in Plant Nematology Laboratory, University of Agriculture, Faisalabad, Pakistan, following the method reported by Khan et al. (2009). The adults of G. mellonella were maintained in plastic jars $(5 \mathrm{~cm}$ diameter and $30 \mathrm{~cm}$ depth), and eggs were collected on folded card sheets. The newly hatched larvae were fed on a semi-natural diet (crushed wheat $500 \mathrm{~g}+$ bee's wax $100 \mathrm{~g}+$ yeast $100 \mathrm{~g}+$ plain/commercial yeast $100 \mathrm{ml}$ ) at the optimum conditions of $31 \pm 1{ }^{\circ} \mathrm{C}$ and $75 \pm 10 \% \mathrm{RH}$ with $24 \mathrm{~h}$ dark photoperiod (Khan et al. 2009).

The larvae of S. litura were collected from the fields of the Entomology Research Area ( $31^{\circ} 26^{\prime} 10^{\prime \prime} \mathrm{N}, 73^{\circ} 03^{\prime}$ 43" E, $184 \mathrm{~m})$ and Postgraduate Agricultural Research Station ( $\left.31^{\circ} 23^{\prime} 30^{\prime \prime} \mathrm{N}, 73^{\circ} 01^{\prime} 00^{\prime \prime} \mathrm{E}, 178 \mathrm{~m}\right)$, University of Agriculture, Faisalabad, Pakistan, and reared on the leaves of cotton plant (Gossypium hirsutum L.), washed, and dried in the laboratory. The larvae were maintained under the controlled conditions of $25 \pm 2{ }^{\circ} \mathrm{C}, 70 \pm 10 \%$ $\mathrm{RH}$, and 12-h photoperiod. The adults of the same age were retained in perspex cages $(30 \times 30 \times 30 \mathrm{~cm})$ ventilated from two parallel sides and fixed with muslin cloth. A cotton wool ball immersed in a solution containing sucrose $(100 \mathrm{~g} / \mathrm{l})$, vitamin solution $(20 \mathrm{ml} / \mathrm{l})$, and methyl 4-hydroxybenzoate $(2 \mathrm{~g} / \mathrm{l})$ was offered in the cages for adult feeding (Ahmad et al. 2009). The test insects were reared in the laboratory for one generation to acquire adequate homogenous larvae for the experiment.

\section{Nematode strains}

The cultures of the two indigenous EPNs, Heterorhabditis indica and Steinernema carpocapsae, were sustained and multiplied on the last instar G. mellonella larvae (Woodring and Kaya 1988) in the laboratory. The larvae infected with EPNs (IJs) were stored at $15{ }^{\circ} \mathrm{C}$, and the deceased or pupating larvae were removed, while in storage. The IJs were collected in clean transparent plastic pots from dead G. mellonella larvae by the modified White trap (White 1927) and kept at $10-15{ }^{\circ} \mathrm{C}$.

\section{Insecticide}

The bio-insecticide, spinosad (Tracer ${ }^{\circ}$ 240SC), that belongs to the toxicological class III of the active ingredient was obtained from Arysta Life Sciences, Pakistan. Serial concentrations of 800, 400, and 200 ppm were prepared by dissolving the measured quantities of the insecticide in distilled water. These concentrations were used alone and in combination with the EPNs for the bioassay tests against the $S$. litura.

\section{Study I: insecticide and EPNs compatibility test}

A simple mortality bioassay test was performed to assess the compatibility of EPNs with the insecticide by using the test serial concentrations. One milliliter of each insecticide concentration was added to a sterilized glass tube, and 100 IJs in $10 \mu l$ Ringer's solution were transferred to each glass tube. The tubes were gently agitated at half an hour intervals to prevent settling of the insecticide and nematode mixture. The experiment was replicated three times with tap water as a control. The mortality data for the EPNs were recorded after 12, 24, and $48 \mathrm{~h}$ of treatment (Ulu et al. 2016). The insecticide concentrations that caused less than $50 \%$ mortality were considered harmless (Khan et al. 2009 and Ahmad et al. 2011).

\section{Study II: efficiency of insecticide and EPNs against Spodoptera litura}

The second and third instar larvae of S. litura, same age sizes, were kept in the plastic containers $(150 \mathrm{ml}$ capacity volume) provided with wet sand $(10 \%, w / w)$ and $5 \mathrm{~g}$ of non-natural larval food. The tested larvae were subjected to treatments given in Table 1 . Ten individuals were treated in each replicate, with a total of three replicates. The nematode concentrations were 100, 200, 500,

Table 1 Combination treatments tested

\begin{tabular}{lll}
\hline Treatments & Product name & Concentration \\
\hline TR & Tracer (spinosad) & $800,400,200 \mathrm{ppm}$ \\
$\mathrm{SC}$ & S. carpocapsae & $1000 \mathrm{IJs}, 500 \mathrm{IJs}, 200 \mathrm{IJs}, 100 \mathrm{IJs}$ \\
$\mathrm{Hi}$ & H. indica & $1000 \mathrm{IJs}, 500 \mathrm{IJs}, 200 \mathrm{IJs}, 100 \mathrm{IJs}$ \\
$\mathrm{SC}+\mathrm{TR}$ & - & $\mathrm{Sc}(1000 \mathrm{IJs})+\mathrm{TR}(800 \mathrm{ppm})$ \\
& & $\mathrm{Sc}(1000 \mathrm{IJs})+\mathrm{TR}(400 \mathrm{ppm})$ \\
& & $\mathrm{SC}(1000 \mathrm{IJs})+\mathrm{TR}(200 \mathrm{ppm})$ \\
$\mathrm{Hi}+\mathrm{TR}$ & - & $\mathrm{Hi}(1000 \mathrm{IJs})+\mathrm{TR}(800 \mathrm{ppm})$ \\
& & $\mathrm{Hi}(1000 \mathrm{IJs})+\mathrm{TR}(400 \mathrm{ppm})$ \\
& & $\mathrm{Hi}(1000 \mathrm{IJs})+\mathrm{TR}(200 \mathrm{ppm})$ \\
Control & Distilled water & \\
\hline
\end{tabular}


and 1000 IJs per container. A single larva was retained in each container, and the mortality data were recorded at 48 and $96 \mathrm{~h}$ post-treatment under the laboratory conditions of $25 \pm 2{ }^{\circ} \mathrm{C}, 70 \pm 10 \% \mathrm{RH}$, and 12-h photoperiod.

\section{Statistical analysis}

All the experiments were performed under completely randomized design (CRD). The larval mortality data were calculated and corrected by using Abbott's formula (Abbott 1925). Data were then subjected to the analysis of variance, and the differences among the means of the treatments' mortality values were estimated through Tukey's HSD test at $P<0.05$. The analysis for additive, antagonistic, or synergistic interactions between the EPNs and insecticide was based on a binomial test and comparison of the expected and observed mortality percentage (Negrisoli et al. 2010). The expected mortality percentage was calculated through the formula:

$$
P_{E}=P_{o}+\left(1-P_{o}\right)\left(P_{1}\right)+\left(1-P_{o}\right)\left(1-P_{1}\right)\left(P_{2}\right)
$$

where $P_{E}$ is designated to the expected mortality in the EPNs and insecticide combination treatment, $P_{O}$ is the mortality in control treatment, $P_{1}$ is the mortality in insecticide treatment, and $P_{2}$ is the mortality observed in the treatment of EPNs alone.

A chi-square $\left(\chi^{2}\right)$ value was calculated by using the formula:

$$
\chi^{2}=\left(L_{o}-L_{e}\right)^{2} / L_{e}+\left(D_{o}-D_{e}\right)^{2} / D_{e}
$$

where $L_{o}$ is the number of living larvae observed in the treatment, $L_{e}$ is the number of living larvae expected in the treatment, $D_{o}$ is the number of dead larvae observed, and $D_{e}$ is the number of dead larvae expected in the treatment.

The hypothesis was tested by using a value of $\chi^{2}=3.84$ at $\mathrm{df}(n-1)$ and $P=0.05$. The additive interaction was explained when $\chi^{2}$ value was less than 3.84 , antagonism was designated to the treatment combinations where observed mortality $\left(P_{o}\right)$ was less than expected mortality $\left(P_{e}\right)$ and $\chi^{2}>3.84$, and synergistic interaction was designated to those treatments, where observed mortality $\left(P_{o}\right)$ was higher than the expected mortality $\left(P_{e}\right)$ and $X^{2}>3.84$ (Negrisoli et al. 2010).

\section{Results and discussion} Insecticide and EPNs compatibility

The compatibility of EPNs with spinosad was performed prior to study their combination against S. litura. The results showed great variations among all the concentrations tested against both EPN species (S. carpocapsae and $H$. indica) after different exposure times $(P<0.05)$. Long exposure time and high concentrations of the insecticide caused low mortality of both EPN species. However, all concentrations of spinosad were considered harmless to the two species, as the treatments demonstrated less than $20 \%$ mortality. The highest concentration $(800 \mathrm{ppm})$ of spinosad showed $14 \%$ mortality in $H$. indica and 13\% in S. carpocapsae juveniles after $48 \mathrm{~h}$ of treatment (Table 2). Negrisoli et al. (2008) recorded low mortality rates of $S$. carpocapsae and H. bacteriophora, when treated with the insecticide Pyrinex ${ }^{\text {rm }}$. Low mortality rates of Steinernema feltiae and S. carpocapsae were observed, when treated with Dursban ${ }^{\text {тu }}$ (Alumai and Grewal 2004) and Gutiérrez et al. 2008).

Relative insusceptibility of EPNs to insecticides can be explained by a hypothesis that in the synapse of EPNs, the existence of the butirilcolinesterase may have a role in this insusceptibility. Selkirk et al. (2001) reported that butirilcolinesterase might defend the acetylcholinesterase because it is attacked by the inhibitors of acetylcholinesrease earlier; therefore, in contrast to such compounds, it is directly involved in the defense. Laznik and Trdan (2014) described the compatibility of EPNs with insecticides as a strain-specific phenomenon and reported that S. feltiae and $H$. bacteriophora were compatible with azadiractin and pirimicarb. The results of this study and those by Laznik and Trdan (2014) proposed that the compatibility of EPNs with selected insecticides may offer cost-effective alternative pest control strategy.

\begin{tabular}{|c|c|c|c|c|c|c|}
\hline \multirow{3}{*}{$\begin{array}{l}\text { Treatment } \\
\text { Tracer }\end{array}$} & \multicolumn{6}{|c|}{ EPN mortality (\%) after treatment application } \\
\hline & \multicolumn{2}{|l|}{ After $12 \mathrm{~h}$} & \multicolumn{2}{|l|}{ After $24 \mathrm{~h}$} & \multicolumn{2}{|l|}{ After $48 \mathrm{~h}$} \\
\hline & $\overline{S C}$ & $\mathrm{Hi}$ & $\overline{S C}$ & $\mathrm{Hi}$ & $\overline{S C}$ & $\mathrm{Hi}$ \\
\hline 200 ppm & $1.33 \pm 0.31 b c^{a}$ & $1.33 \pm 0.33 c^{a}$ & $4.33 \pm 0.88 b^{a}$ & $5.00 \pm 0.57 c^{a}$ & $7.33 \pm 0.33 c^{a}$ & $9.00 \pm 0.51 b^{a}$ \\
\hline 400 ppm & $3.00 \pm 0.57 b$ & $5.00 \pm 0.51 b$ & $6.73 \pm 0.88 b$ & $7.00 \pm 0.51 b$ & $9.34 \pm 0.31 b$ & $11.00 \pm 0.57 b$ \\
\hline 800 ppm & $6.34 \pm 0.34 a$ & $8.00 \pm 0.51 a$ & $9.34 \pm 0.34 a$ & $10.67 \pm 0.34 a$ & $13.00 \pm 0.51 a$ & $14.00 \pm 0.57 a$ \\
\hline Control & $0.00 \pm 0.00 c$ & $0.00 \pm 0.00 c$ & $0.00 \pm 0.00 c$ & $0.00 \pm 0.00 d$ & $0.00 \pm 0.00 \mathrm{~d}$ & $0.00 \pm 0.00 c$ \\
\hline $\begin{array}{l}\text { Statistics } \\
\text { summary }\end{array}$ & $\begin{array}{l}F=53.87, P=0.000 \\
D F=11, R^{2}=95.28 \%\end{array}$ & $\begin{array}{l}F=67.57, P=0.000 \\
D F=11, R^{2}=96.20 \%\end{array}$ & $\begin{array}{l}F=36.80, P=0.000 \\
D F=11, R^{2}=93.24 \%\end{array}$ & $\begin{array}{l}F=101.71, P=0.000 \\
D F=11, R^{2}=97.45 \%\end{array}$ & $\begin{array}{l}F=215.67, P=0.000 \\
D F=11, R^{2}=98.32 \%\end{array}$ & $\begin{array}{l}F=145.33, P=0.000 \\
D F=11, R^{2}=98.20 \%\end{array}$ \\
\hline
\end{tabular}

Table 2 Toxicity of Tracer $^{\circledast}$ 240SC against the entomopathogenic nematode species

${ }^{a}$ Means sharing different letters in a column are statistically different by the Tukey test at $5 \%$ Probability 
Efficiency of spinosad and EPNs against S. litura

In the present study, spinosad seemed to be an important factor in larval mortality. The second and third larval instars of S. litura, treated with spinosad and EPNs and their combination, showed significant differences in mortality percentage among all treatments $48 \mathrm{~h}$ post-treatment $\left(F=41.64 ; \mathrm{df}=53 ; P<0.001 ; R^{2}=95.16 \%\right.$ and $F=16.66 ; \mathrm{df}=53 ; P<0.001 ; R^{2}=88.72 \%$, respectively). Higher concentration ( $800 \mathrm{ppm}$ ) of spinosad alone showed high mortalities of 66.67 and $43.33 \%$ in the second and third larval instars of S. litura, respectively, after $48 \mathrm{~h}$ (Table 3). S. carpocapsae and $H$. indica showed less mortality in the second instar larvae even with the highest number of IJs (1000/treatment), whereas no mortality was observed with the lowest numbers (200 and 100/treatments) after 48 h of treatment. Treatment with EPNs alone caused 16.67 and $10.00 \%$ mortality rates in the second and third larval instars, respectively, in $H$. indica, when treated with 1000 IJs (Table 3). The efficiency of the lowest concentration (100 IJs) of both EPNs was not satisfactory; about $<4 \%$ mortality was found after $48 \mathrm{~h}$ (Table 3). Radhakrishnan and Shanmugam (2017) demonstrated that by increasing the dose rates of $H$. indica and S. glaseri, high mortality rates were observed in S. litura under lab conditions, and $H$. indica proved to be more effective under pot culture conditions in the greenhouse. Guo et al. (2013) reported a high reduction in the population of Holotrichia parallela by using high dose rates (5000-10,000 IJs/ plant) of Steinernema longicaudum and H. bacteriophora in the peanut field.

Using the combination of spinosad (at $800 \mathrm{ppm}$ ) with S. carpocapsae, 80 and $50 \%$ mortality rates of the second and third larval instars, respectively, after $48 \mathrm{~h}$ were observed. Similar results of high efficacy were observed in $H$. indica combined with spinosad at $800 \mathrm{ppm}$ (Table 3).

After $96 \mathrm{~h}$, the mortality rate of the second $(F=91.79$; $\left.\mathrm{df}=53, P<0.001 ; R^{2}=97.74 \%\right)$ and third $(F=46.51 ; \mathrm{df}=$ $\left.53, P<0.001 ; R^{2}=95.65 \%\right)$ instar larvae of $S$. litura showed a significant increase. The highest concentration of spinosad $(800 \mathrm{ppm})$ alone, as well as its mixture with $1000 \mathrm{IJs}$ of each of the EPN species, demonstrated 100\% mortality of the second instar larvae (Table 4). Similarly, 76.67\% mortality rate of the third instar larvae was observed, using spinosad $(800 \mathrm{ppm})$ alone, and its efficiency increased by 10-20\%, when applied with both EPNs. These findings are in accordance with Negrisoli et al. (2010) who stated that in the field circumstances, mortality of the

Table 3 Interaction between Tracer and entomopathogenic nematode species over mortality rate (mean \pm SE) of the second and third larval instars of Spodoptera litura after $48 \mathrm{~h}$ of treatment application

\begin{tabular}{|c|c|c|c|c|c|c|}
\hline \multirow[t]{2}{*}{ Treatments* } & \multicolumn{6}{|c|}{ Observed mortality (\%) and interactive response between treatments } \\
\hline & Second instar & $x^{2}$ & Response $^{c}$ & Third instar & $x^{2}$ & Response $^{* * *}$ \\
\hline Tracer 800 ppm & $66.67 \pm 6.67 a b^{* *}$ & - & - & $43.33 \pm 3.34 a b^{* *}$ & - & - \\
\hline Tracer 400 ppm & $40.00 \pm 5.77 \mathrm{~cd}$ & - & - & $23.33 \pm 3.34 \mathrm{bcde}$ & - & - \\
\hline Tracer 200 ppm & $16.67 \pm 6.67 \mathrm{ef}$ & - & - & $6.67 \pm 3.33 \mathrm{ef}$ & - & - \\
\hline SC $1000 \mathrm{IJS}$ & $13.33 \pm 3.33 e f$ & - & - & $3.33 \pm 3.33 \mathrm{ef}$ & - & - \\
\hline Sc $500 \mathrm{lJS}$ & $3.33 \pm 3.33 \mathrm{ef}$ & - & - & $0.00 \pm 0.00 f$ & - & - \\
\hline SC $200 \mathrm{IJS}$ & $0.00 \pm 0.00 f$ & - & - & $0.00 \pm 0.00 f$ & - & - \\
\hline SC $100 \mathrm{lJS}$ & $0.00 \pm 0.00 f$ & - & - & $0.00 \pm 0.00 f$ & - & - \\
\hline Hi $1000 \mathrm{lJs}$ & $16.67 \pm 6.6 \mathrm{ef}$ & - & - & $10.00 \pm 5.77 \mathrm{ef}$ & - & - \\
\hline Hi $500 \mathrm{lJs}$ & $6.67 \pm 3.33 \mathrm{ef}$ & - & - & $3.33 \pm 3.33 \mathrm{ef}$ & - & - \\
\hline Hi $200 \mathrm{lJS}$ & $3.33 \pm 3.33 \mathrm{ef}$ & - & - & $0.00 \pm 0.00 f$ & - & - \\
\hline Hi $100 \mathrm{lJs}$ & $0.00 \pm 0.00 f$ & - & - & $0.00 \pm 0.00 f$ & - & - \\
\hline Sc + TR 800 ppm & $80.00 \pm 5.77 a$ & 39.69 & Synergistic & $50.00 \pm 5.77 a$ & 1.31 & Additive \\
\hline Sc + TR 400 ppm & $53.33 \pm 3.33 b c$ & 20.54 & Synergistic & $36.67 \pm 6.67 a b c$ & 1.81 & Additive \\
\hline Sc + TR 200 ppm & $43.33 \pm 3.34 \mathrm{~cd}$ & 54.92 & Synergistic & $16.67 \pm 6.67 \mathrm{cdef}$ & 1.54 & Additive \\
\hline $\mathrm{Hi}+\mathrm{TR} 800$ ppm & $76.67 \pm 3.33 a$ & 7.02 & Synergistic & $40.00 \pm 5.77 a b$ & 16.73 & Synergistic \\
\hline $\mathrm{Hi}+\mathrm{TR} 400$ ppm & $43.33 \pm 3.34 \mathrm{~cd}$ & 12.1 & Synergistic & $33.33 \pm 3.33 \mathrm{abcd}$ & 1.11 & Additive \\
\hline Hi + TR 200 ppm & $23.33 \pm 6.67 \mathrm{de}$ & 1.87 & Additive & $13.33 \pm 8.82 \mathrm{def}$ & 0.00 & Additive \\
\hline Control & $0.00 \pm 0.00 f$ & - & - & $0.00 \pm 0.00 f$ & - & - \\
\hline
\end{tabular}

*Treatments: TR $=$ Tracer $^{\circledast} 240 \mathrm{SC}, \mathrm{Sc}=\mathrm{S}$. carpocapsae and Hi $=\mathrm{H}$. indica; Sc + TR (S. carpocapsae $1000 \mathrm{IJs}+$ respective concentration of insecticide), Hi + TR (H. indica $1000 \mathrm{IJs}+$ respective concentration of insecticide), **sharing different letters are statistically different by the Tukey test at $5 \%$ Probability, $* * * i n t e r a c t i v e$ response between treatment mixtures: synergistic $\left(x^{2}>3.84\right.$ and observed mortality $>$ expected mortality), additive $\left(x^{2}<3.84\right)$, and antagonistic $\left(x^{2}>3.84\right.$ and observed mortality < expected mortality) 
Table 4 Interaction between Tracer and entomopathogenic nematode species over mortality rate (mean \pm SE) of the second and third larval instars of Spodoptera litura after $96 \mathrm{~h}$ of treatment application

\begin{tabular}{|c|c|c|c|c|c|c|}
\hline \multirow[t]{2}{*}{ Treatments* $^{*}$} & \multicolumn{6}{|c|}{ Observed mortality (\%) and interactive response between treatments } \\
\hline & Second instar & $x^{2}$ & Response $^{c}$ & Third instar & $x^{2}$ & Response $e^{* * *}$ \\
\hline Tracer 800 ppm & $100.00 \pm 0.00 a^{* *}$ & - & - & $76.67 \pm 3.33 a b^{* *}$ & - & - \\
\hline Tracer 400 ppm & $63.33 \pm 3.33 \mathrm{~cd}$ & - & - & $50.00 \pm 5.77 \mathrm{~cd}$ & - & - \\
\hline Tracer 200 ppm & $50.00 \pm 5.77 \mathrm{de}$ & - & - & $33.33 \pm 3.33 \mathrm{de}$ & - & - \\
\hline SC 1000 IJS & $63.33 \pm 3.33 \mathrm{~cd}$ & - & - & $46.67 \pm 3.34 \mathrm{~cd}$ & - & - \\
\hline SC 500 IJS & $33.33 \pm 3.33 \mathrm{ef}$ & - & - & $33.33 \pm 3.33$ de & - & - \\
\hline SC 200 IJS & $20.00 \pm 5.77 \mathrm{fg}$ & - & - & $10.00 \pm 5.77 \mathrm{ef}$ & - & - \\
\hline SC 100 IJS & $3.33 \pm 3.33 \mathrm{gh}$ & - & - & $0.00 \pm 0.00 f$ & - & - \\
\hline Hi 1000 IJS & $60.00 \pm 5.77 \mathrm{~cd}$ & - & - & $33.33 \pm 6.67 \mathrm{de}$ & - & - \\
\hline Hi 500 IJS & $33.33 \pm 3.33 \mathrm{ef}$ & - & - & $20.00 \pm 5.77 \mathrm{ef}$ & - & - \\
\hline Hi 200 IJS & $13.33 \pm 3.33 \mathrm{gh}$ & - & - & $6.67 \pm 3.33 f$ & - & - \\
\hline Hi 100 IJS & $0.00 \pm 0.00 \mathrm{~h}$ & - & - & $0.00 \pm 0.00 f$ & - & - \\
\hline Sc + TR 800 ppm & $100.00 \pm 0.00 a$ & 11.28 & Synergistic & $96.67 \pm 3.33 a$ & 30.67 & Synergistic \\
\hline $\mathrm{Sc}+\mathrm{TR} 400 \mathrm{ppm}$ & $86.67 \pm 3.33 a b$ & 17.82 & Synergistic & $70.00 \pm 5.77 b c$ & 28.73 & Synergistic \\
\hline Sc + TR 200 ppm & $73.33 \pm 3.33 b c$ & 17.56 & Synergistic & $50.00 \pm 5.77 \mathrm{~cd}$ & 12.10 & Synergistic \\
\hline $\mathrm{Hi}+\mathrm{TR} 800$ ppm & $100.00 \pm 0.00 a$ & 12.73 & Synergistic & $86.67 \pm 6.68 \mathrm{ab}$ & 20.50 & Synergistic \\
\hline $\mathrm{Hi}+\mathrm{TR} 400 \mathrm{ppm}$ & $70.00 \pm 5.77 b c$ & 10.8 & Synergistic & $76.67 \pm 3.33 a b$ & 21.63 & Synergistic \\
\hline$H i+$ TR 200 ppm & $56.67 \pm 3.33 \mathrm{~cd}$ & 8.89 & Synergistic & $46.67 \pm 6.67 \mathrm{~cd}$ & 0.20 & Additive \\
\hline Control & $0.00 \pm 0.00 \mathrm{~h}$ & - & & $0.00 \pm 0.00 f$ & - & \\
\hline
\end{tabular}

*Treatments: TR $=$ Tracer $^{\circledast} 240 \mathrm{SC}, \mathrm{SC}=\mathrm{S}$. carpocapsae and Hi= H. indica; SC + TR (S. carpocapsae $1000 \mathrm{IJs}+$ respective concentration of insecticide), Hi $+\mathrm{TR}$ (H. indica $1000 \mathrm{IJs}+$ respective concentration of insecticide), ${ }^{* *}$ sharing different letters are statistically different by the Tukey test at $5 \%$ probability, ${ }^{* * *}$ interactive response between treatment mixtures: synergistic $\left(x^{2}>3.84\right.$ and observed mortality $>$ expected mortality), additive $\left(x^{2}<3.84\right)$, and antagonistic $\left(x^{2}>3.84\right.$ and observed mortality < expected mortality)

third instar larvae of $S$. frugiperda was significantly different after application of insecticide + EPNs as compared to EPNs alone. Obtained results indicated also that the nematode species, insecticide concentrations, and their mixtures had a little more effect on the second instar larvae than the third instar after 48 and $96 \mathrm{~h}$ of treatment (Tables 3 and 4).

Synergistic and additive interaction of spinosad and EPNs mixtures against Spodoptera litura

All the mixtures of spinosad and EPN species showed synergistic interactions against the second instar larvae after $48 \mathrm{~h}$ of treatment, except for the treatment spinosad $(200 \mathrm{ppm})+H$. indica juveniles $\left(\chi^{2}=1.87\right)$; however, the interaction was additive. The highest mortality rate of the second instar larvae was observed by using the mixtures of S. carpocapsae or H. indica with $800 \mathrm{ppm}$ of spinosad showing synergistic interactions $\left(\chi^{2}>3.84\right)$. In the case of the third instar larvae, a mixture of $S$. carpocapsae and spinosad $(800 \mathrm{ppm})$ was found to be additive $\left(\chi^{2}=1.31\right)$ while that of $H$. indica was synergism $\left(\chi^{2}=16.73\right)$ after $48 \mathrm{~h}$ of treatment (Table 3 ).

After $96 \mathrm{~h}$ of treatment, all the combinations (EPNs + spinosad, all concentrations) exhibited synergistic interactions $\left(x^{2}>3.84\right)$, except the combination of $H$. indica and $200 \mathrm{ppm}$, which presented an additive effect $\left(\chi^{2}=0.20\right)$ (Table 4). Less than $10 \%$ mortality was observed in the treatments with a low number of IJs (100 and $200 \mathrm{IJs}$ ) of both species against the third instar larvae after $96 \mathrm{~h}$ of treatment. The results obtained from these experiments indicated that the nematode species, insecticide concentrations, and their mixtures were more effective against the second instar larvae than the third instar larvae after 48 and $96 \mathrm{~h}$ of treatment. Guo et al. (2016) reported a synergistic or an additive effect of combinations of $H$. bacteriophora with chlorantraniliprole and imidacloprid on the second instar larvae of Holotrichia oblita, causing faster mortality than the nematode species or insecticide alone. When high concentrations of the insecticides were combined with nematodes, the strongest synergistic effects were found.

\section{Conclusions}

The present study highlighted two major findings: (1) the EPNs, $S$. carpocapse, and $H$. indica were compatible and had a synergistic interaction with spinosad (Tracer ${ }^{\circ}$ 240SC) against two larval instars of S. litura, and (2) young larval instars of $S$. litura were more susceptible to insecticide and nematode-spinosad mixtures. Therefore, 
they are recommended for early applications for a better pest management. The efficacy of nematodes and biorational insecticides depends upon certain environmental factors when applied under field conditions. Hence, there is a need of exploration for more EPN isolates and evaluating optimal nematode concentrations in combination with particular insecticides in the laboratory and field conditions.

\section{Abbreviations}

EPNs: Entomopathogenic nematodes; Hi: Heterorhabditis indica;

Sc: Steinernema carpocapsae; TR: Tracer (spinosad)

\section{Acknowledgements}

The authors are thankful to the Department of Plant Pathology, University of Agriculture, Faisalabad, Pakistan, for providing the facilities for the experiments.

\section{Availability of data and materials}

Data will not be shared.

\section{Authors' contributions}

All authors read and approved the final manuscript.

\section{Ethics approval and consent to participate}

Not applicable

\section{Consent for publication}

Not applicable

\section{Competing interests}

The authors declare that they have no competing interests.

\section{Publisher's Note}

Springer Nature remains neutral with regard to jurisdictional claims in published maps and institutional affiliations.

\section{Author details}

${ }^{1}$ Department of Plant Protection, Directorate General of Agriculture and Livestock Research, Ministry of Agriculture and Fisheries, PO Box 50 Seeb, 121 Muscat, Sultanate of Oman. ${ }^{2}$ Department of Entomology, University of Agriculture, Faisalabad 38040, Pakistan. ${ }^{3}$ Department of Plant Pathology, University of Agriculture, Faisalabad 38040, Pakistan. ${ }^{4}$ Department of Entomology, University of Sargodha, Sargodha 40100, Pakistan.

Received: 17 May 2018 Accepted: 27 June 2018

Published online: 19 July 2018

\section{References}

Abbott WS (1925) A method of computing the effectiveness of an insecticide. J Econ Entomol 18:265-267

Ahmad M, Arif MI (2010) Resistance of beet armyworm Spodoptera exigua (Lepidoptera: Noctuidae) to endosulfan, organophosphorous and pyrethroid insecticides in Pakistan. Crop Prot 29(12):1428-1433

Ahmad M, Saleem MA, Ahmad M (2005) Time-oriented mortality in leaf worm, Spodoptera litura (Fab.) (Lepidoptera: Noctuidae) by some new chemistry insecticides. Pak Entomol 27(1):67-70

Ahmad M, Saleem MA, Sayyed AH (2009) Efficacy of insecticide mixtures against pyrethroid- and organophosphate-resistant populations of Spodoptera litura (Lepidoptera: Noctuidae). Pest Manag Sci 65:266-274

Ahmad S, Ashfaq M, Khan RR, Khan HAA (2011) Toxicity of some insecticides against Bracon hebetor (Say): a potential lepidopterous parasitoid. Kuwait J Sci Eng 38(2A):185-192

Akhurst R, Smith K (2002) Regulation and safety. In: Gaugler R (ed) Entomopathogenic nematology. CABI, New York, pp 311-332

Alumai A, Grewal PS (2004) Tank-mix compatibility of the entomopathogenic nematodes, Heterorhabditis bacteriophora and Steinernema carpocapsae, with selected chemical pesticides used in turfgrass. Biol Sci Technol 14(6):613-618
Dhir BC, Mohapatra HK, Senapati B (1992) Assessment of crop loss in groundnut due to tobacco caterpillar, Spodoptera litura (Fab.). Indian J Plant Protect 20(2):215-217

Grewal PS, Koppenhöfer AM, Choo HY (2005) Lawn, turfgrass and pasture applications. In: Grewal PS, Ehlers RU, Shapiro-llan DI (eds) Nematodes as biocontrol agents. CABI, Wallingford, pp 115-146

Guo W, Yan X, Zhao G, Han R (2016) Increased efficacy of entomopathogenic nematode-insecticide combinations against Holotrichia oblita (Coleoptera: Scarabaeidae). J Econ Entomol:1-11. https://doi.org/10.1093/jee/tow241

Guo WX, Yan X, Zhao GY, Han RC (2013) Efficacy of entomopathogenic Steinernema and Heterorhabditis nematodes against white grubs (Coleoptera: Scarabaeidae) in peanut fields. J Econ Entomol 106:1112-1117

Gutiérrez C, Campos-Herrera R, Jimenez J (2008) Comparative study of the effect of selected agrochemical products on Steinernema feltiae (Rhabditida: Steinernematidae). Biocontrol Sci Tech 18(1):101-108

Khan RR, Ashfaq M, Ahmad S, Sahi ST (2009) Mortality responses in Bracon hebetor (Say.) (Braconidae: Hymenoptera) against some new chemistry and conventional insecticides under laboratory conditions. Pak J Agri Sci 46(1):30-33

Laznik $\breve{Z}$, Trdan S (2014) The influence of insecticides on the viability of entomopathogenic nematodes (Rhabditida: Steinernematidae and Heterorhabditidae) under laboratory conditions. Pest Manag Sci 70(5):784-789

Negrisoli AS, Garcia MS, Negrisoli CRCB, Bernardi D, da Silva A (2010) Efficacy of entomopathogenic nematodes (Nematoda: Rhabditida) and insecticide mixtures to control Spodoptera frugiperda (Smith, 1797) (Lepidoptera: Noctuidae) in corn crops. Crop Protect 29:677-683

Negrisoli AS Jr, Barbosa CRC, Moino A Jr (2008) Comparação entre metodologias de avaliaçaõvalicompatibilidade de produtos fitossanitaŕios com nematoídes entomopatogênicos (Nematoda: Rhabditida). Nematologia Brasileira 32(1):65-75

Radhakrishnan S, Shanmugam S (2017) Bioefficacy of entomopathogenic nematodes against Spodoptera litura (Lepidoptera: Noctuidae) in Bhendi. Int J Curr Microbiol Appl Sci 6(7):2314-2319

Rojht H, KaČ M, Trdan S (2009) Non-target effect of entomopathogenic nematodes on larvae of two spotted lady beetle (Coleoptera: Coccinellidae) and green lacewing (Neuroptera: Chrysopidae) under laboratory conditions. J Econ Entomol 102:1440-1443

Saleem MA, Ahmad M, Aslam M, Sayyed AH (2008) Resistance to selected organochlorine, organophosphate, carbamate and pyrethroid in Spodoptera litura (Lepidoptera: Noctuidae) from Pakistan. J Econ Entomol 101:1667-1675

Selkirk ME, Henson SM, Russel WS, Hussein AS (2001) Acetylcholinesterase secretion by nematodes. In: Kennedy MW, Harnett W (eds) Parasitic nematodes: molecular biology, biochemistry and immunology. CABI Publishing, New York, pp 211-229

Shapiro-llan DI, Gouge DH, Piggott SJ, Fife JP (2006) Application technology and environmental consideration for use of entomopathogenic nematodes in biological control. Biol Control 38:124-133

Ulu TC, Sadic B, Susurluk IA (2016) Effects of different pesticides on virulence and mortality of some entomopathogenic nematodes. ISJ-Invert Surviv J 13:111-115

White GF (1927) A method for obtaining infective nematode larvae from cultures. Science 66:302-303

Wilson L, Mensah R, Dillon M, Wade M, Scholz B, Murray D et al (2002) Impact of insecticides and miticides on predators in cotton, December 2002 update, IPM guidelines supporting document I, Australian Cotton Cooperative Research Center, Narrabri, New South Wales, Australia, p 2

Woodring JL, Kaya HK (1988). Steinernematid and Heterorhabditid nematodes: a handbook of biology and techniques. Southern cooperative series bulletin 331. Arkansas Agric. Exp. Stat., Fayetteville, Arkansas, USA

Wu CJ, Fan SY, Jiang YH, Zhang AB (2004) Inducing gathering effect of taro on Spodoptera litura (Fab.). Chinese J Ecol 23:172-174

Zhou Z, Chen Z, Xu Z (2010) Potential of trap crops for integrated management of the tropical armyworm, Spodoptera litura (Fab.) in tobacco. J Insect Sci 10(117). https://doi.org/10.1673/031.010.11701 